\title{
KEDUDUKAN HASIL TES DNA DALAM PENETAPAN STATUS HUKUM ANAK LUAR NIKAH
}

\author{
Muh. Bacbrul Ulum*
}

\begin{abstract}
Marriage law states that the descent of somebody can only be approved by birth certificate or decision from a Religious Court, based on sufficient evidences. DNA as one evidence is a blue print which explains the blood relation that can be descended to the next generation. However, the validity of this test is still hesitated. It is because the test is still insufficient as a powerful proof which can be used in courts.
\end{abstract}

Kata kunci: tes $D N A$, anak luar nikah, alat bukti

\section{A. Pendahuluan}

Hubungan hukum (nasab) atau asal-usul seseorang dapat timbul dan diketahui dari salah satu di antara tiga sebab, yaitu: kelahiran (al-firäsh), pengakuan (al-iqrär) dan berdasar alat bukti yang sah (al-bayyinah). Seorang anak yang dilahirkan dari perkawinan orang tuanya yang sah merupakan anak sah yang tentu saja memiliki hubungan hukum (nasab) dengan kedua orang tuanya. Sedangkan anak di luar nikah adalah anak yang dilahirkan di luar perkawinan yang sah. Akan tetapi status seorang anak yang dilahirkan dalam perkawinan yang sah dapat juga diingkari oleh ayah atau ibunya.

\footnotetext{
'Penulis adalah Magister Hukum, dosen tetap Jurusan Syari'ah STAIN Purwokerto.
} 
Hubungan nasab antara anak dan ibu yang melahirkannya tidak terlalu menjadi persoalan karena anak yang berada dalam kandungannya jelas siapa pemiliknya. Berbeda halnya dengan hubungan nasab antara anak dengan bapaknya. Seorang bapak memiliki hak untuk mengingkari benih yang tumbuh dalam rahim seorang wanita.

Penetapan status hukum asal usul anak (ithbät al-nasab) merupakan dasar untuk menetapkan adanya hubungan nasab dengan kedua orang tuanya, khususnya hubungan biologis. Anak sah memiliki hubungan nasab dengan kedua orang tuanya, sedangkan bagi anak yang dilahirkan di luar nikah atau anak zina menurut hukum perkawinan Indonesia hanya mempunyai hubungan nasab dengan ibu dan saudara ibunya. Penetapan status hukum anak sangatlah penting karena terkait dengan hubungan keperdataan, yakni hubungan perwalian, perkawinan, kewajiban orang tua terhadap anak dan sebaliknya serta hubungan pewarisan.

Undang Undang Nomor 1 tahun 1974 tentang Perkawinan mengatur tentang status hukum seorang anak dalam pasal 42, 43, 44 dan 55. Pasal 42 menyatakan bahwa "anak sah adalah anak yang dilahirkan dalam atau akibat perkawinan yang sah.” Perkawinan yang sah sendiri didefinisikan sebagai perkawinan yang memenuhi syarat yang diatur dalam pasal 2 UU Perkawinan. "Anak yang dilahirkan diluar perkawinan hanya mempunyai hubungan perdata dengan ibunya dan keluarga ibunya" (Pasal 43). Seorang suami dapat menyangkal sahnya anak yang dilahirkan oleh isterinya bilamana ia dapat membuktikan bahwa isterinya telah berzina dan anak itu akibat dari perzinaan tersebut. "Pengadilan memberikan keputusan tentang sah tidaknya anak atas permintaan pihak yang bersangkutan" (Pasal 44). Pasal 55 tentang pembuktian asal usul anak menegaskan bahwa pada prinsipnya asal usul seorang anak hanya dapat dibuktikan dengan Akta Kelahiran yang otentik yang dikeluarkan oleh pejabat yang berwenang atau dengan alat bukti lainnya. Apabila akta kelahiran tidak ada, maka Pengadilan Agama dapat mengeluarkan penetapan tentang asal usul seorang anak setelah diadakan pemeriksaan yang teliti berdasarkan bukti-bukti yang memenuhi syarat. Berdasarkan 
penetapan tersebut dikeluarkan Akta Kelahiran bagi anak yang bersangkutan oleh instansi pencatat kelahiran (Kantor Catatan Sipil) yang ada dalam daerah hukum yang bersangkutan. ${ }^{1}$

Di dalam Pasal 102 ayat 1 dan 2 Undang Undang Nomor 1 tahun 1974 dijelaskan bahwa suami yang akan mengingkari seorang anak yang lahir dari isterinya dapat mengajukan gugatan ke Pengadilan Agama dalam jangka waktu 180 hari sesudah hari lahirnya atau 360 hari sesudah putusnya perkawinan atau setelah suami itu mengetahui bahwa isterinya melahirkan anak dan berada di tempat yang tidak memungkinkan dia mengajukan perkaranya ke Pengadilan Agama. Pengingkaran yang diajukan sesudah lewat waktu tidak dapat diterima. Persoalan muncul manakala bukti bahwa isterinya telah berzina baru diketahui setelah lewat waktu dari yang ditentukan oleh undang-undang tersebut. Alat bukti yang digunakan berkaitan dengan pembuktian pengingkaran dan atau pengakuan anak adalah:

1. Akta kelahiran anak (yang telah dibukukan dalam register catatan sipil);

2. Saksi-saksi. Hal ini dapat dilakukan bila tidak ada akta kelahiran. Pembuktian dengan saksi ini hanya boleh dilakukan apabila telah ada bukti permulaan dengan tulisan, dugaan-dugaan, dan petunjuk-petunjuk yang tersimpul dari peristiwa-peristiwa yang tidak dapat disangkal lagi kebenarannya;

3. Pengadilan mewajibkan yang berkepentingan untuk mengucapkan sumpah (Penjelasan pasal 44 UU Perkawinan);

4. Melakukan tes DNA. Tes ini dapat membuktikan jenis darah dari pihak yang mengingkari dan yang diingkari, yang kemudian dapat dipakai untuk memperkirakan adanya hubungan darah antara keduanya.

${ }^{1}$ Ketentuan tersebut diatur pula dalam Pasal 103 ayat (1) dan (2) Kompilasi Hukum Islam. Lihat pula Sudarsono, Hukum Perkaninan Nasional (Jakarta: Rineka Cipta, 2005), hal. 195-196 
Undang-Undang No. 23 Tahun 2002 tentang Perlindungan Anak menegaskan bahwa setiap anak berhak untuk mengetahui orang tuanya, dibcsarkan dan diasuh oleh orang tuanya sendiri. Hak anak untuk mengetahui siapa orang tuanya (asal usulnya) bertujuan untuk menghindari terputusnya silsilah dan hubungan darah antara anak dengan orang tua kandungnya. Sedangkan hak anak untuk dibesarkan dan diasuh olch orang tuanya dimaksudkan agar anak dapat patuh dan menghormati orang tuanya. ${ }^{2}$

Hubungan nasab dan hubungan perdata seorang anak dengan orang tuanya selain karena kelahiran, dapat juga dengan pengakuan maupun putusan hakim atas dasar pembuktian. Pengakuan acialah pengakuan seseorang (ayah atau ibu) kepada seorang anak bahwa anak itu adaiah anak kandungnya. Hal ini tentu saja harus memenuki syarat-syarat tertentu, seperti:

1. Anak yang mendapat pegakuan itu sebelumnya memang tidak diketahui asal-usulnya (nasabnya) sama sckali.

2. Pengakuan tersebut dapat diterima oleh akal sehat.

3. Terbukti secara hukum bahwa ia bukanlah anak zina.

4. Jika anak yang diakui itu sudah mumayyiz pengakuan tersebut tidak bolch ditoiak oleh anak tersebut.

5. Orang yang mengakui tersebut berakal sehat.

Sedangkan yang dimaksud dengan penetapan asal-usul dengan dasar pembuktian terjadi jika seseorang mengajukan gugatan permohonan penetapan asal-usul anak tetapi disangkal oleh pihak lawan. Untuk membuktikan kebenaran dari gugatan tersebut, penggugat wajib mengajukan alat bukti yang sah. Salah satu bukti modern adalah dengan mempergunakan hasil tes DNA. Penetapan status hukum asal usul seorang anak dapat diajukan oleh isteri, anak, ataupun oleh bapaknya. Sebagai dasar untuk membuktikan hubungan nasab dapat dilakukan melalui proses pemeriksaan medis

\footnotetext{
${ }^{2}$ Darwan Prinst, Hukum Anak Indonesia, (Citra Aditya Bakti: Bandung, 2003), hal.
} 151. 
berupa tes DNA (DeoxyriboNucleic Acid). Pihak medis (Dokter ahli forensik/genetika di laboratorium/rumah sakit) mengeluarkan surat resmi yang berisikan penjelasan mengenai hasil tes darah tersebut serta adanya kesaksian dari dokter sebagai keterangan ahli yang dapat memberikan penjelasan dan kesaksian dihadapan sidang pengadilan dalam penyelesaian kasus pembuktian anak luar kawin (anak zina).

\section{B. DNA dan Perannya dalam Penyelesaian Masalah Hukum}

Asam deoksiribonukleat atau lebih dikenal dengan nama DNA (DeoxyriboNucleic Acid) merupakan asam nukleat yang menyimpan semua informasi tentang genetika. Secara terminologis DNA adalah persenyawaan kimia yang membawa keterangan genetik dari sel khususnya atau dari makhluk dalam keseluruhannya dari suatu generasi ke generasi berikutnya. ${ }^{3} \mathrm{DNA}$ inilah yang menentukan jenis rambut, warna kulit, dan sifat-sifat khusus dari manusia. DNA pada dasarnya merupakan cetak biru (blue print) ciri khas manusia yang dapat diturunkan kepada generasi selanjutnya. Oleh karena itu komposisi DNA dalam tubuh seorang anak sama dengan tipe DNA dari orang tuanya. Sedangkan tes DNA adalah metode untuk mengidentifikasi fragmen-fragmen dari DNA itu sendiri yaitu untuk mengidentifikasi, menghimpun, dan menginventarisir file-file khas karakter tubuh. Hampir semua sampel biologis tubuh dapat digunakan untuk sampel tes DNA, tetapi yang sering digunakan adalah darah, rambut, usapan mulut pada pipi bagian dalam (buccal swab), dan kuku. ${ }^{4}$

DNA yang biasa digunakan dalam tes ada dua yaitu DNA mitokondria dan DNA inti sel. Perbedaan kedua DNA ini hanyalah terletak pada lokasi DNA tersebut berada dalam sel. Sampel DNA yang paling akurat digunakan dalam tes adalah DNA inti sel, karena inti sel tidak bisa berubah. DNA dalam mitokondria dapat berubah karena berasal dari garis keturunan ibu yang dapat berubah seiring dengan perkawinan dan keturunannya. Tetapi karena keunikan dari

\footnotetext{
${ }^{3}$ Suryo, Genetika Manusia (Yogyakarta: Gajah Mada University Press, 1994), hal. 57.

${ }^{4}$ Sinly Evan Putra, "Di Balik Teknologi Tes DNA," dalam bttp://www.chem-is-try.org.
} 
pola pewarisan DNA mitokondria menyebabkan DNA mitokondria dapat dijadikan sebagai marka (penanda) untuk tes DNA dalam upaya mengidentifikasi hubungan kekerabatan secara maternal.

Metode yang banyak digunakan adalah RFLP (Restriction Fragment Length Polymorphisme) dan STR (Short Tandem Repeat). RFLP memiliki tingkat akurasi paling tinggi tetapi juga tingkat kesulitan tinggi. Metode STR lebih praktis dan akurasinya dapat disesuaikan tergantung jumlah lokus yang dianalisis. RFLP adalah perbedaan urutan DNA pada kromosom homolog yang menghasilkan pola fragmen atau potongan yang berbeda di seluruh genom. Analisis RFLP merupakan metode ampuh untuk pendeteksian kemiripan dan perbedaan sampel DNA yang hanya membutuhkan darah atau jaringan lain dalam jumlah sedikit. DNA yang berbeda dari setiap orang akan menghasilkan potongan-potongan DNA yang berbeda pula. Perbedaan ini mendasari metode RFLP pada setiap DNA yang berbeda. Karena sidik jari DNA merupakan untaian DNA yang unik pada setiap orang, jika dilakukan analisis fragmen-fragmen restriksi DNA pada genom orang, tidak perlu seluruh DNA dalam genom dianalisis tetapi difokuskan pada suatu urutan tertentu yang memang sangat bervariasi dari satu orang ke orang lain. Analisis menggunakan DNA inti memiliki akurasi yang tinggi karena dirujuk pada DNA inti kedua orangtua (diploid). Kelemahan metode ini adalah bila salah satu atau kedua orang tua tidak ada. Penggunaan DNA inti saudara seayah-ibu, anak, paman, dan bibi atau kakek dan nenek kandung memerlukan koreksi berdasarkan segregasi Mendel. Sedangkan generasi ketiga atau saudara sepupu, tidak dapat digunakan. ${ }^{5}$

Akurasi tes DNA hampir mencapai $100 \%$. Kesalahan kemiripan pola DNA yang terjadi secara random (kebetulan) sangat kecil kemungkinannya, mungkin satu diantara satu juta. Jika terdapat kesalahan, hal itu disebabkan oleh faktor buman error, terutama pada kesalahan interprestasi fragmen-fragmen DNA oleh operator (manusia). Tetapi dengan menerapkan prosedur standard yang tepat

\footnotetext{
${ }^{5}$ Fahrudin, "Tes DNA Sebagai Alat Pembuktian," dalam wnw.tribun-timur.com.
} 
maka kesalahan manusia (buman error) dapat diminimalisir atau bahkan ditiadakan.

Tes DNA biasanya dipergunakan dalam menyelesaikan kasuskasus yang berkaitan dengan :

1. Pelacakan asal-usul keturunan, seperti kasus perebutan anak, penentuan perwalian anak, penentuan orang tua dari anak yang dilahirkan serta kasus- kasus hukum kekeluargaan lainnya.

2. Masalah forensik, seperti identifikasi korban yang telah hancur, sehingga untuk mengenali identitasnya diperlukan pencocokan antara DNA korban dengan terduga keluarga korban ataupun untuk pembuktian kejahatan semisal dalam kasus pemerkosaan atau pembunuhan.

\section{Penetapan Status Hukum Anak Dengan Tes DNA}

Para pihak yang berperkara di Pengadilan agar dapat terkabul permohonannya maka harus mampu membuktikannya bahwa ia mempunyai alas hak atau berada dalam posisi yang benar. Nilai pembuktian tidak bersifat mutlak, sehingga kebenaran yang dicapai bersifat relatif. Pembuktian dalam ilmu hukum hanya sebagai upaya untuk memberikan keyakinan terhadap fakta-fakta yang dikemukakan agar logis dan selaras dengan kebenaran. Akan tetapi mempunyai nilai yang cukup signifikan karena berfungsi memberikan kepastian tentang kebenaran fakta hukum yang menjadi pokok sengketa bagi hakim. Oleh karena itu hakim akan berpedoman dalam menjatuhkan putusannya dari hasil pembuktian.

Pasal 163 HIR menegaskan bahwa barang siapa yang mendalilkan sesuatu maka dia yang harus membuktikan. Berdasar pasal tersebut beban pembuktian terletak kepada kedua belah pihak dan para pihak diwajibkan untuk menghadirkan alat bukti. Alat bukti (bewijsmidde) bermacam-macam bentuk dan jenisnya. Alat bukti tersebut diajukan oleh para pihak untuk membenarkan dalil gugat atau dalil bantahan dalam pemeriksaan persidangan. Berdasarkan keterangan dan penjelasan yang diberikan alat bukti itulah hakim melakukan penilaian, pihak mana yang paling kuat dan paling 
sempurna pembuktiannya. Mengenai alat bukti yang diakui dalam Hukum Acara Perdata diatur secara enumeratif dalam Pasal 1866 KUH Perdata dan Pasal 164 HIR, yang hingga kini belum ada pembaruan atau perubahan mengenai jenis atau bentuk alat bukti, yakni terdiri dari:

1. Bukti tulisan/surat,

2. Bukti saksi,

3. Persangkaan,

4. Pengakuan, dan

5. Sumpah. ${ }^{6}$

Konsep penemuan hukum terhadap alat bukti tes Deoxyribo Nucleic Acid (DNA) dilakukan dengan menggunakan metode penemuan hukum argumentum per analogium (analogi) dan metode eksposisi verbal deskripsi, yaitu suatu penafsiran undang-undang yang dilakukan dengan cara memberikan kias atau ibarat pada kata-kata yang terdapat dalam undang-undang sesuai dengan asas hukumnya. Dengan demikian suatu peristiwa yang sebenarnya tidak dapat dimasukan lalu diangap atau dibaratkan sesuai dengan bunyi peraturan tersebut. ${ }^{7}$ Alat bukti tes DNA ini bila diajukan di persidangan dapat hadir dan dikategorikan sebagai bentuk alat bukti surat, alat bukti saksi, maupun alat bukti petunjuk.

Alat bukti surat adalah segala sesuatu yang memuat tandatanda bacaan yang dimaksudkan untuk mencurahkan isi hati atau untuk menyampaikan buah pikiran seseorang dan dipergunakan sebagai pembuktian. ${ }^{8}$ Alat bukti surat dapat berupa surat biasa maupun akta. Akta dibedakan menjadi akta otentik dan akta di bawah tangan. Akta adalah suatu surat yang ditandatangani, diperbuat untuk dipakai sebagai alat bukti dan unttuk dipergunakan oleh orang

\footnotetext{
${ }^{6}$ Retnowulan Sutanto dan Iskandar Oeripkartawinata, Hukum Acara Perdata Dalam Teori dan Praktek (Bandung: Mandar Maju, 1997), hal. 61.

${ }^{7}$ Chainur Arrasjid, Dasar-Dasar Ilmu Hukum (Jakarta, Sinar Grafika, 2001), hal. 94.

${ }^{8}$ Sudikno Mertokusumo, Hukum Acara Perdata Indonesia (Yogyakarta: Liberty,1985), hal. 120 .
} 
untuk keperluan siapa surat itu dibuat. ${ }^{9}$ Akta otentik adalah akta yang dibuat oleh atau dihadapan pegawai umum yang berkuasa membuatnya, yakni notaris, hakim, panitera, pegawai pencatat sipil, pegawai pencatat nikah, PPAT, dan sebagainya. Sedangkan akta di bawah tangan adalah segala tulisan yang memang sengaja dibuat untuk dijadikan bukti tetapi tidak dibuat dihadapan atau oleh pejabat yang berwenang dan bentuknyapun tidak perlu terikat kepada bentuk tertentu. ${ }^{10}$ Akta di bawah tangan baru mempunyai kekuatan bukti materil jika telah dibuktikan kekuatan formilnya dan kekuatan formilnya baru terjadi setelah pihak-pihak yang bersangkutan mengakui akan kebenaran isi dan cara pembuatan akta tersebut dan bagi hakim merupakan bukti bebas. ${ }^{11}$

Bukti tes DNA merupakan akta di bawah tangan karena bukti tes DNA berupa surat resmi yang dikeluarkan oleh paramedis/dokter (bukan pegawai umum sebagaimana ketentuan Pasal $1868 \mathrm{KUH}$ Perdata) sebagai bukti yang menerangkan ada tidaknya kesamaan DNA atau hubungan darah. Apabila dibandingkan dengan alat bukti dalam KUHAP yang menyebutkan bahwa akta di bawah tangan yaitu surat keterangan dari seorang ahli yang memuat pendapat berdasarkan keahliannya, tampak eksistensinya pada Pasal 187 huruf c KUHAP seperti visum et repertum, surat keterangan ahli tentang sidik jari (daktiloskopi), surat keterangan ahli tentang kedokteran kehakiman, dan sebagainya. ${ }^{12}$ Dari perbandingan tersebut, jelas bahwa surat keterangan dokter tentang hasil tes DNA dapat dianalogikan dengan visum et repertum yang merupakan akta di bawah tangan. Sebagai alat bukti akta di bawah tangan maka surat keterangan dokter tentang hasil tes DNA merupakan bukti bebas. Itu berarti bahwa

\footnotetext{
${ }^{9}$ A. Pitlo, Pembuktian dan Dalunarsa (Jakarta: Intermasa, 1978), hal. 52.

${ }^{10}$ Roihan A. Rasyid, Hukum Acara Peradilan Agama (Jakarta: Raja Grafindo Persada, 1996), hal. 154.

${ }^{11}$ A. Mukti Arto, Praktek Perkara Perdata Pada Pengadilan Agama (Yogyakarta: Pustaka Pelajar, 1998), hal. 145 - 146; bandingkan Teguh Samudera, Hukum Pembuktian dalam Acara Perdata (Bandung: Alumni, 1992), hal. 52-53.

${ }^{12}$ Lilik Mulyadi, Hukum Acara Pidana: Normatif, Teoritis, Praktek dan Permasalahannya (Bandung: Alumni , 2007), hal. 187.
} 
hakim bebas untuk mempergunakan atau mengesampingkan alat bukti ini. Kekuatan pembuktiannya digantungkan kepada para pihak apakah mengakui atau mengingkari kebenaran formil dan materil dari surat tersebut, apabila diakui maka menjadi alat bukti yang sempurna bahwa hasil tes DNA yang menyatakan bahwa seorang anak merupakan anak kandung dari bapaknya, tanpa perlu penambahan pembuktian lagi begitupula sebaliknya. Akan tetapi validitas tes DNA yang dilakukan di Indonesia belum diakui secara penuh karena keterbatasan teknologi dan sumber daya. Oleh karena itu agar perkara tersebut lebih terang, hakim dapat menjadikannya sebagai bukti permulaan dengan menambah alat bukti lain berupa keterangan dokter sebagai saksi ahli agar menjadi sempurna.

Pendapat serupa dinyatakan oleh Komisi Bahtsul Masail Nahdlatu Ulama yang menolak uji DNA untuk menentukan hubungan kekeluargaan seseorang secara syar'i. Anak di luar nikah dengan bapaknya secara biologis bisa dinasabkan, tetapi tidak sesuai dengan syara'. Menurut syariat Islam, nasab didasarkan kepada perkawinan yang sah. Ketidakjelasan nasab akan membawa pada perkara hukum yang lain, seperti waris. Jika ia tidak bisa dinasabkan secara syar'i, maka ia tidak bisa mendapatkan hak waris. Tes DNA dapat dijadikan sebagai penetapan bahwa seseorang itu memiliki hubungan dengan orang lain. Oleh karena itu tes DNA dalam ilhạq al-nasab (hubungan nasab/keturunan) bisa dijadikan sebagai bagian yang akan mendukung boleh tidaknya seseorang itu diakui sebagai nasab. ${ }^{13}$

Bahtsul Masail sendiri berpendapat bahwa hasil tes DNA bisa menjadi bukti bahwa seseorang memiliki hubungan biologis dengan orang tertentu. Akan tetapi menurut syara' semata-mata hasil tes DNA saja tidak bisa serta merta mengindikasikan status seorang anak sebagai sah atau tidak, sebab hal itu amat terkait dengan proses perkawinan. Seseorang itu diakui dan dianggap sebagai anak yang

${ }^{13}$ Maktab Daimi, "Nasab Biologis Berbeda Dengan Nasab Syar'i," dalam bttp:// wvvv. rabithah. net. 
sah, dan memperolah hak-haknya dalam waris, apabila ia lahir dari hasil pernikahan yang sah. Karena hasil tes DNA hanya menentukan hubungan keturunan itu secara biologis saja, dan tidak diketahui secara syar'i hubungan tersebut sah atau tidak, maka hal itu tidak bisa serta merta bisa ditentukan sebagai dasar hukum bahwa yang bersangkutan memiliki hubungan yang sah dengan orang lain yang dianggap sebagai orang tua kandungnya. Oleh karena itu setelah tes DNA masih dibutuhkan sekian informasi lainnya untuk menetapkan bahwa yang bersangkutan memiliki hubungan dengan orang lain, seperti melalui penyaksian dan sebagainya. Tes DNA hanya merupakan salah satu bagian saja dari infomasi yang banyak tersebut. Jadi semata-mata berdasarkan hasil tes DNA saja belum bisa digunakan untuk memutuskan bahwa seseorang bernasab kepada orang lain secara sah menurut syara'. ${ }^{14}$

Penggunaan tes DNA yang berkaitan dengan pelacakan asal usul keturunan dalam penetapan status anak di luar nikah (zina) dapat dijadikan sebagai bukti primer yang dapat berdiri sendiri tanpa perlu diperkuat dengan alat bukti lainnya, dengan alasan: ${ }^{15}$

1. DNA langsung diambil dari tubuh yang dipersengketakan dan dari yang bersengketa, sehingga tidak mungkin adanya rekayasa.

2. Unsur-unsur yang terkandung dalam DNA seseorang berbeda dengan DNA orang lain kecuali memiliki garis keturunan dekat sehingga kesimpulan yang dihasilkan cukup valid.

Apabila hakim merasa ragu akan validitas metode dan hasil tes DNA maka hasil tes DNA belum dapat menjadi alat bukti utama dan masuk ke dalam kategori alat bukti persangkaan (petunjuk/ qarinab) yang diberikan oleh saksi ahli. Persangkaan adalah kesimpulan yang oleh undang-undang atau oleh hakim ditarik dari suatu peristiwa yang dikenal kearah peristiwa yang belum terjadi. Alat bukti persangkaan merupakan alat pembuktian tidak langsung,

${ }^{14}$ Ibid.

15 Taufiqul Hulam, Reaktualisasi Alat Bbukti Tes DNA: Perspektif Hukum Islam dan Hukum Positif (Yogyakarta: UII-Press, 2002), hal. 130. 
karena hakim dalam mengambil kesimpulan harus menghubungkan dan menyesuaikan dengan alat bukti lainnya. Tes DNA dapat menjadi jalan yang mengarahkan kepada pembuktian terhadap penentuan status anak luar nikah (anak zina) melalui identifikasi terhadap petunjuk-petunjuk yang diambil dari organ tubuh oleh seorang ahli genetika. Oleh karena itu DNA merupakan alat bukti pelengkap yang boleh digunakan hakim sebagai jalan untuk memutuskan perkara. Kekuatan pembuktian persangkaan dari alat bukti tes DNA ini adalah bebas, terserah pada hakim untuk menggunakannya sebagai alat bukti yang sempurna atau alat bukti permulaan atau bahkan mengesampingkannya sama sekali.

\section{Penutup}

Anak luar nikah atau anak zina menurut hukum perkawinan Indonesia memiliki hubungan nasab dan hubungan keperdataan dengan ibu dan keluarga ibunya. Seorang Bapak dapat melakukan pengingkaran terhadap seorang anak apabila dapat membuktikan bahwa isterinya telah melakukan zina dan anak yang dikandung atau dilahirkannya merupakan anak hasil zina, sepanjang tidak melampaui waktu yang ditentukan oleh undang-undang. Akan tetapi orang tua juga dapat melakukan pengakuan terdapatnya hubungan darah terhadap anaknya atau sebaliknya serta atas putusan hakim berdasar gugatan dari salah satu pihak dengan alat bukti yang cukup dan otentik. Salah satu alat bukti modern yang dapat menunjukkan hubungan darah seseorang adalah dengan menggunakan tes DNA.

Alat bukti tes DNA belum merupakan alat bukti sebagaimana yang disebutkan secara enumeratif dalam Pasal 164 HIR. Akan tetapi berdasarkan penafsiran analogi maka tes DNA ini dapat dikategorikan sebagai alat bukti surat, yaitu akta di bawah tangan, berupa surat yang dikeluarkan oleh pejabat yang berwenang (dokter forensik/ahli genetika) yang sengaja dibuat sebagai alat bukti untuk menunjukkan adanya hubungan darah berdasarkan kesamaan DNA. Akan tetapi karena validitas tes DNA khususnya di Indonesia masih diragukan, Hakim dapat mempergunakan hasil tes DNA sebagai alat 
bukti persangkaan atau bukti permulaan yang masih memerlukan alat bukti lain untuk memperkuat. Kekuatan pembuktian alat bukti tes DNA adalah bebas, jadi tergantung dari hakim itu sendiri untuk menggunakan sebagai alat bukti yang sempurna atau alat bukti permulaan atau mengesampingkan keberadaan alat bukti ini.

\section{DAFTAR PUSTAKA}

Arrasjid, Chainur. Dasar - Dasar Ilmu Hukum. Jakarta: Sinar Grafika, 2001.

Arto, A. Mukti. Praktek Perkara Perdata Pada Pengadilan Agama. Yogyakarta: Pustaka Pelajar, 1998.

Daimi, Maktab. Nasab Biologis Berbeda Dengan Nasab Syar'i, dalam bttp://wnvw. rabithah. net.

Fahrudin. Tes DNA sebagai alat pembuktian, dalam www.tribuntimur.com.

Hulam, Taufiqul. Reaktualisasi Alat Bukti Tes DNA: Perspektif Hukum Islam dan Hukum Positif. Yogyakarta: UII Press, 2002.

Mertokusumo, Sudikno. Hukum Acara Perdata Indonesia. Yogyakarta: Liberty,1985.

Mulyadi, Lilik. Hukum Acara Pidana: Normatif, Teoritis, Praktek dan Permasalabannya. Bandung: Alumni, 2007.

Pitlo, A. Pembuktian dan Daluwarsa. Jakarta: Intermasa, 1978.

Prinst, Darwan. Hukum Anak Indonesia. Bandung: Citra Aditya Bakti, 2003.

Putra, Sinly Evan. Di Balik Teknologi Tes DNA. Dalam bttp:// www.chem-is-try.org.

Ramulyo, Mohd. Idris. Hukum Perkawinan Islam: Suatu Analisis dari Undang-Undang No. 1 Tabun 1974 dan Kompilasi Hukum Islam. Jakarta: Bumi Aksara, 1996. 
Muh. Bachrul Ulum

Rasyid, Roihan A. Hukum Acara Peradilan Agama. Jakarta: Raja Grafindo Persada, 1996.

Sutanto, Retnowulan dan Iskandar Oeripkartawinata. Hukum Acara Perdata dalam Teori dan Praktek. Bandung: Mandar Maju, 1997.

Sudarsono. Hukum Perkawinan Nasional. Jakarta: Rineka Cipta, 2005. Suryo. Genetika Manusia. Yogyakarta: Gajah Mada University Press, 1994.

Samudera, Teguh. Hukum Pembuktian dalam Acara Perdata. Bandung: Alumni, 1992. 